\title{
Mauste- ja rohdoskasvien raskasmetallit
}

\author{
Bertalan Galambosi ${ }^{1)}$, Marja Roitto ${ }^{1)}$, Jorma Kumpulainen ${ }^{2)}$, Leila Lindstedt ${ }^{3)}$ \\ ${ }^{1)}$ MTT, Ympäristöntutkimus, Ekologinen tuotanto, Karilantie 2A, 50600 Mikkeli, \\ e-mail:etunimi.sukunimi@mtt.fi \\ ${ }^{2)}$ MTT, Elintarvikkeiden tutkimus, 31600 Jokioinen \\ ${ }^{3)}$ MTT, Ympäristöntutkimus, 31600 Jokioinen
}

\section{Johdanto}

Kadmium $(\mathrm{Cd})$ ja lyijy $(\mathrm{Pb})$ ovat terveydelle haitallisia raskasmetalleja. Lehtivihannesten ja tuoreiden yrttien korkeimmat sallitut Cd-pitoisuudet ovat $0.2 \mathrm{ppm}$ (EU, komission asetus 466/2001). Vastaavasti lehtivihannesten korkein sallittu lyijypitoisuus on $0.3 \mathrm{ppm}$ tuorepainoa kohden. KeskiEuroopassa on tutkittu paljon myös rohdoskasvien raskasmetallipitoisuuksia. Saksassa rohdoskasvien raja-arvoiksi on ehdotettu $0.2 \mathrm{ppm}(\mathrm{Cd})$ ja 5 ppm $(\mathrm{Pb})$ kuiva-ainekiloa kohden laskettuna (Schilcher 1994). Joillekin lajeille on ehdotettu em. arvoista poikkeavia korkeampia enimmäispitoisuuksia (Schilcher 1994, Kabelitz 1998). Tällaisia lajeja ovat esimerkiksi mäkikuisma ja siankärsämö.

Tämän työn tavoitteena oli tutkia Suomessa ja muualla Euroopassa tuotettujen yrtti- ja rohdoskasvien lyijy- ja kadmiumpitoisuuksia.

\section{Aineisto ja menetelmät}

Tässä tutkimuksessa mitattiin lyijyn $(\mathrm{Pb})$ ja kadmiumin $(\mathrm{Cd})$ kertymistä mauste- ja rohdoskasveihin. Aineisto koostui 230 kotimaisesta ja 168 ulkomaisesta kasvinäytteestä, mittauksia tehtiin viidestäkymmenestä eri kasvilajista vuosina 1989-1990. Suurin osa tutkitusta materiaalista oli herbaja lehtinäytteitä (74\%), mutta myös kukkanäytteitä (11\%) ja maustekasvien siemeniä (10\%) analysoitiin. Kotimaiset näytteet saatiin rohdos- ja yrttikasvien viljelykokeista sekä kaupallisilta tuottajilta. Eurooppalaiset vertailunäytteet saatiin tutkimuslaitoksilta sekä kaupallisilta tuottajilta Saksasta, Itävallasta, Unkarista, Tšekkoslovakiasta, Britanniasta, Italiasta, Puolasta ja Turkista.

Lisäksi vertailtiin vuosina 1990 ja 2003 Etelä-Savossa Puumalassa ja Mikkelissä viljeltyjen kasvien raskasmetallipitoisuuksia. Tutkitut lajit olivat kamomilla, kumina, meirami. sitruunamelissa, oregano, nokkonen, rakuuna, lipstikka, mäkikuisma, siankärsämö, kynteli, kultapiisku, iisoppi, persilja, timjami, piparminttu, salvia, anisiisoppi, tilli, korianteri, ampiaisyrtti, ukontulikukka, reunuspäivänkakkara ja punahattu.

Analyyseihin käytettiin kuivattuja ja jauhettuja kasvinäytteitä. Raskasmetallipitoisuudet määritettiin märkäpoltetuista näytteistä atomiabsorptiospektrometrilla (ETAAS) (Tahvonen ja Kumpulainen, 1991). Vuoden 2003 näytteiden lyijy- ja kadmiumpitoisuudet mitattiin plasmaemissiospektrometrilla (ICP-MS PESCIEX ELAN 6000).

\section{Tulokset ja tulosten tarkastelu}

Ulkomaisten näytteiden lyijypitoisuudet olivat keskimäärin kaksinkertaisia verrattuna kotimaisiin näytteisiin (Kuva 1). 64\% muiden maiden ja 11\% suomalaisten näytteiden lyijypitoisuuksista ylitti 1 ppm. Kadmiumpitoisuudet ylittivät 0.2 ppm $26 \%$ ulkomaisissa ja $11 \%$ kotimaisissa näytteissä (Kuva 2). Myös Suomessa tuotettujen yrttien raskasmetallipitoisuuksissa oli selviä eroja eri paikkakuntien välillä.

Eri kasvilajien kadmiumpitoisuudet vaihtelivat suuresti. Kotimaisen nokkosen, piparmintun ja anisiisopin Cd-pitoisuudet jäivät alhaisiksi $(<0.01 \mathrm{ppm})$. Toisaalta rakuunan, mäkikuisman, ampiaisyrtin ja kamomillan keskimääräiset Cd-pitoisuudet ylittivät 0.15 ppm. Korkeimmat yksittäiset Cd-pitoisuudet mitattiin rakuunan $(1.49 \mathrm{ppm})$ ja persiljan $(0.93 \mathrm{ppm})$ lehdistä.

Vuonna 2003 Etelä-Savossa tuotettujen kasvien lyijypitoisuudet olivat selvästi alhaisempia verrattuna vuoden 1990 näytteisiin (Kuva 3). Huomattavaa on, että kadmiumpitoisuudet eivät pienentyneet vastaavana tarkasteluajankohtana (Kuva 3). Tosin tulokset ovat vain suuntaa antavia, sillä kasvupaikkojen ja -kausien väliset erot voivat olla myös huomattavia. 


\section{Johtopäätökset}

Tulokset osoittavat, että Suomella on edellytykset tuottaa puhtaita yrtti- ja rohdoskasveja. Koska osa rohdoskasveista kerää helposti maaperän kadmiumia, on viljelyalueiden ja kasvilajien valinta kuitenkin tehtävä huolellisesti.

Kabelitz, L. 1998. Heavy metals in herbal drugs. Eur. J. Herb. Med. 4:1-9

Schilcher, H. 1994. Zur Frage der Schadstoffe in Arznei- und Gewürzpflanzen sowie der Zubereitungen Übersicht und aktuelle rechtliche Bewertung von Rückstanden. Herba Germanica 2:11-18.

Tahvonen, R. \& Kumpulainen, J. 1991. Lead and cadmium in berries and vegetables on the Finnish market 1987-1989. Fresenius J. Anal. Chem. 340:242-244.

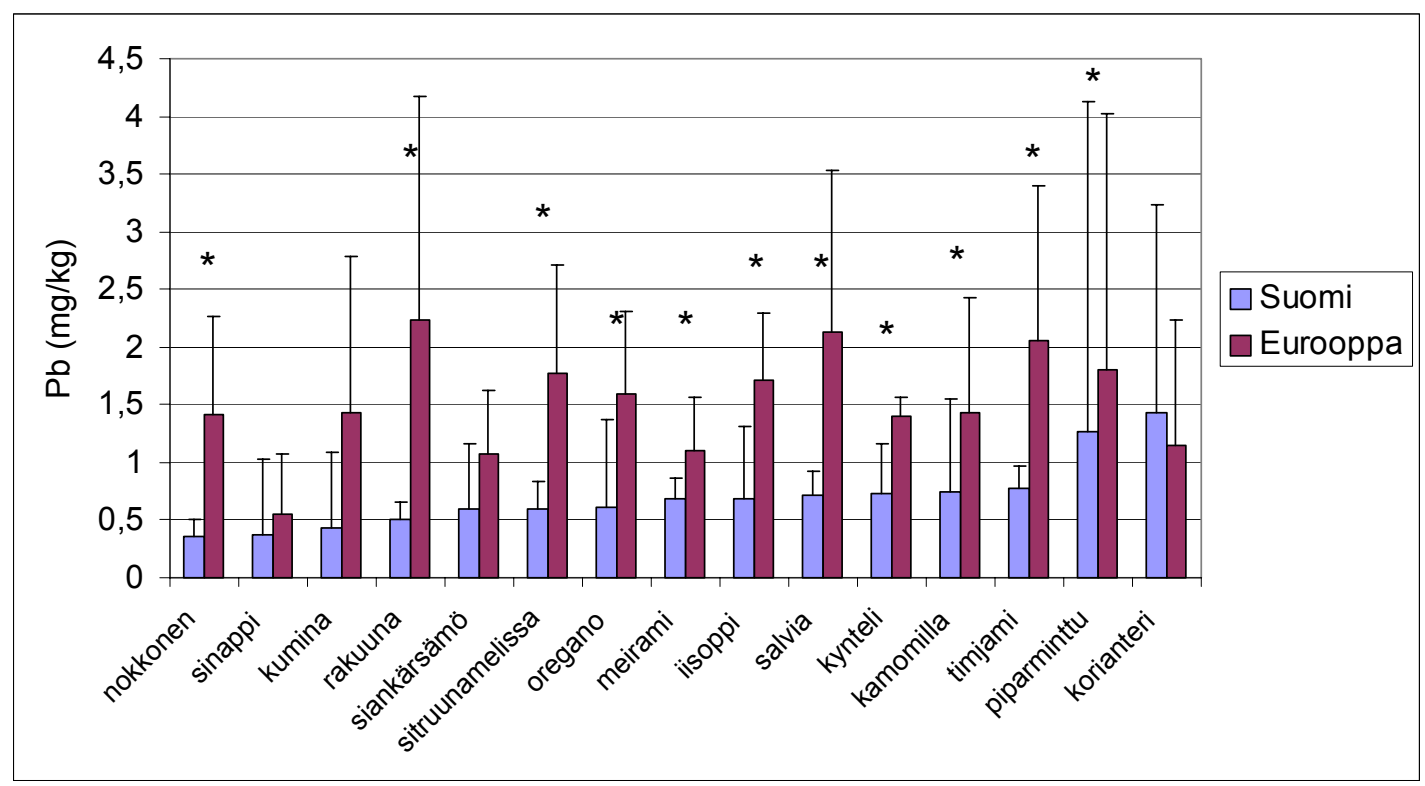

Kuva 1. Vuoden 1990 näytteiden lyijypitoisuudet Suomessa ja Euroopan muista maista kootuissa mauste- ja rohdoskasveissa (keskiarvo \pm SD). Tähdet ilmaisevat tilastollista ero näytteiden välillä. Kotimaiset näytteet saatiin rohdos- ja yrttikasvien viljelykokeista sekä kaupallisilta tuottajilta. Eurooppalaiset vertailunäytteet saatiin tutkimuslaitoksilta sekä kaupallisilta tuottajilta Saksasta, Itävallasta, Unkarista, Tšekkoslovakiasta, -Britanniasta, Italiasta, Puolasta ja Turkista. 


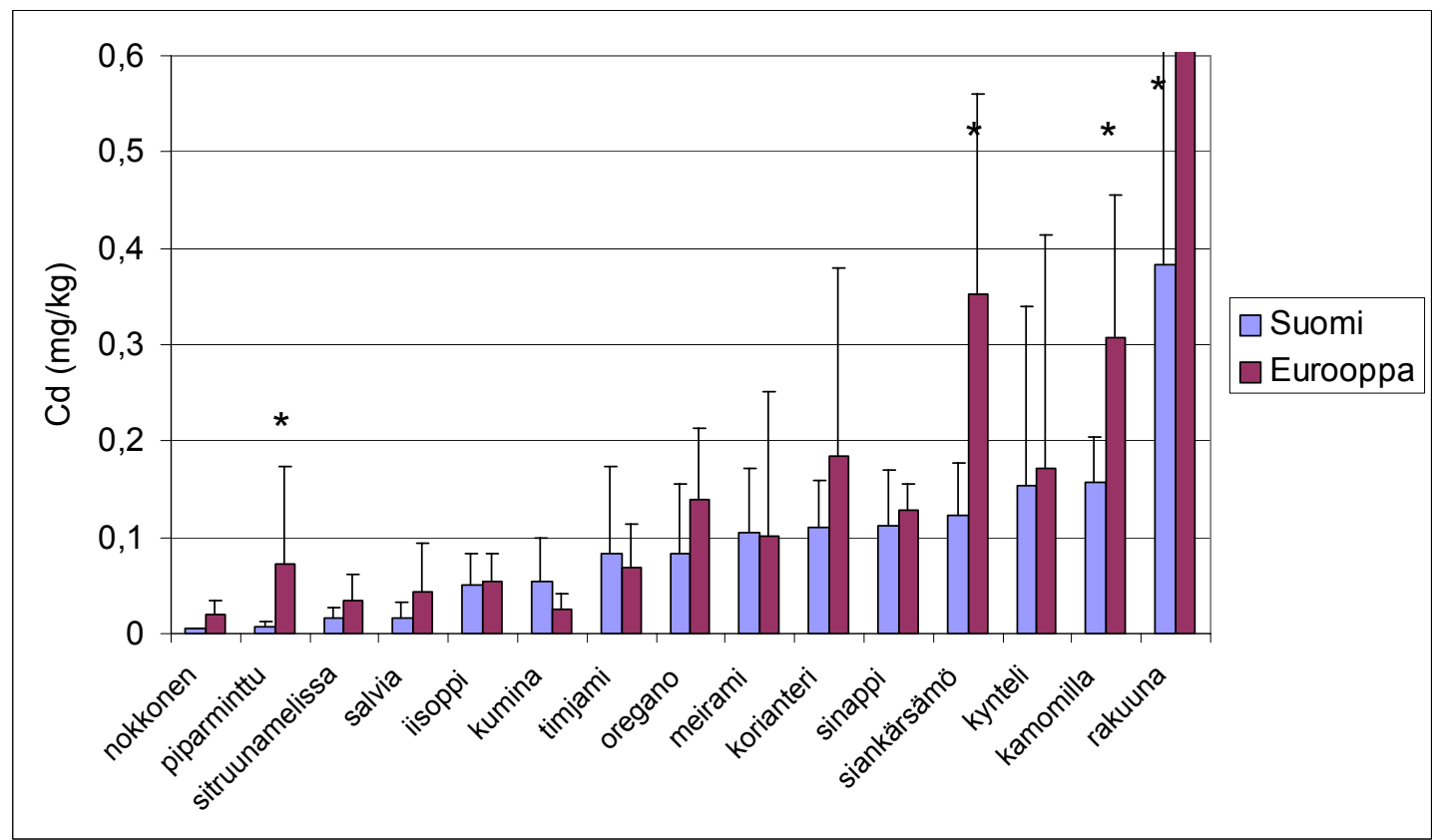

Kuva 2. Vuoden 1990 näytteiden kadmiumpitoisuudet Suomessa ja Euroopan muista maista kootuissa mauste- ja rohdoskasveissa (keskiarvo \pm SD). Tähdet ilmaisevat tilastollista ero näytteiden välillä. Kotimaiset näytteet olivat peräisin rohdos- ja yrttikasvien viljelykokeista sekä kaupallisilta tuottajilta. Eurooppalaiset vertailunäytteet saatiin tutkimuslaitoksilta sekä kaupallisilta tuottajilta Saksasta, Itävallasta, Unkarista, Tšekkoslovakiasta, Britanniasta, Italiasta, Puolasta ja Turkista.

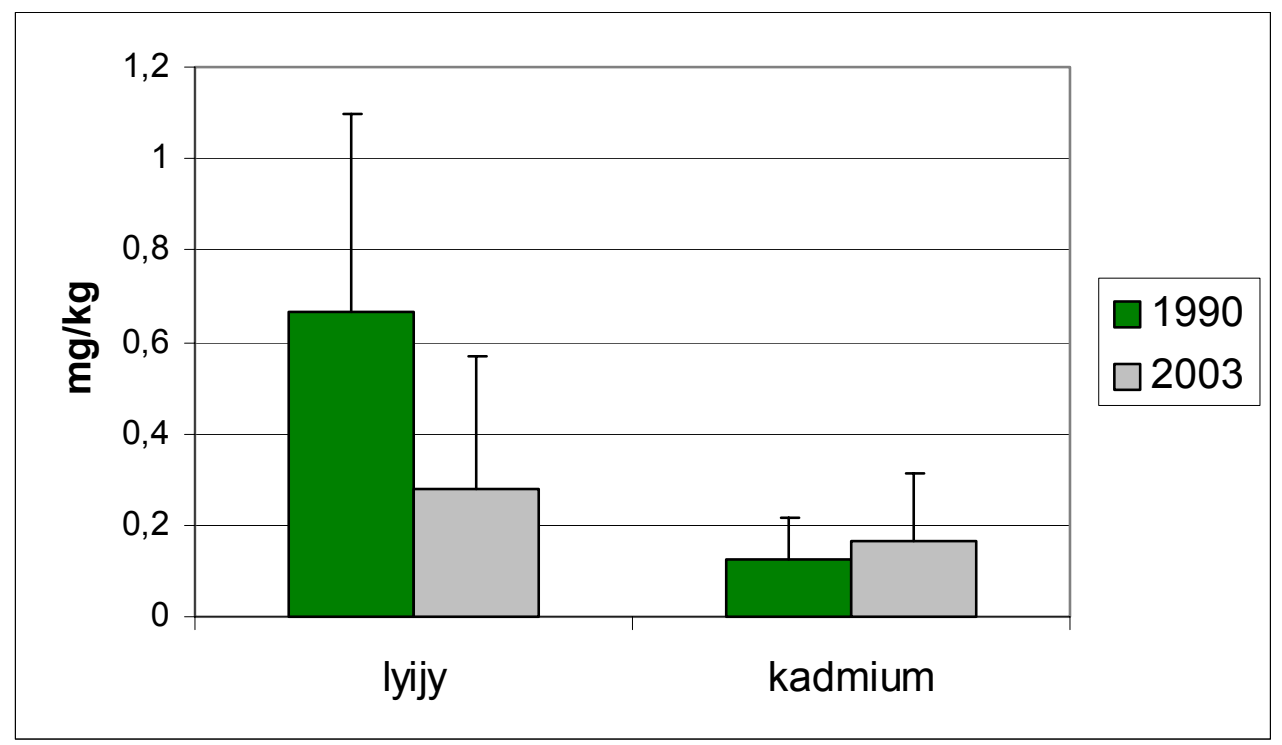

Kuva 3. Vuosina 1990 ja 2003 Etelä-Savossa mitattujen yrttien- ja rohdoskasvien keskimääräiset lyijy ja kadmiumpitoisuudet $( \pm \mathrm{SD}) . \mathrm{n}=25$. 